Report of Investigations 2001-1D

\title{
ENGINEERING-GEOLOGIC MAP OF THE CHULITNA REGION, SOUTHCENTRAL ALASKA
}

by

D.S. Pinney

2001

This DGGS Report of Investigations is a final report of scientific research. It has received technical review and may be cited as an agency publication.

Research supported in part by the U.S. Geological Survey, National Cooperative Geologic Mapping Program, under USGS award number 98HQA G2083. The views and conclusions contained in this document are those of the authors and should not be interpreted as necessarily representing the official policies, either expressed or implied, of the U.S. Government. 


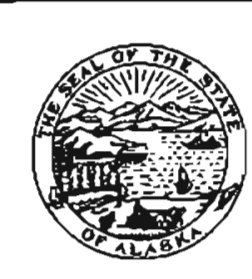

STATE OF ALASKA

Tony Knowles, Governor

DEPARTMENT OF NATURAL RESOURCES

Pat Pourchot, Commissioner

\section{DIVISION OF GEOLOGICAL \& GEOPHYSICAL SURVEYS Milton A. Wiltse, Director and State Geologist}

Division of Geological \& Geophysical Surveys publications can be inspected at the following locations. Address mail orders to the Fairbanks office.

Alaska Division of Geological

\& Geophysical Surveys

794 University Avenue, Suite 200

Fairbanks, Alaska 99709-3645

Elmer E. Rasmuson Library

University of Alaska Fairbanks

Fairbanks, Alaska 99775-1005
University of Alaska Anchorage Library 3211 Providence Drive

Anchorage, Alaska 99508

\author{
Alaska Resource Library \\ 3150 C Street, Suite 100 \\ Anchorage, Alaska 99503
}

Alaska State Library

State Office Building, 8th Floor

333 Willoughby Avenue

Juneau, Alaska 99811-0571

This publication released by the Division of Geological \& Geophysical Surveys was produced and printed in Fairbanks, Alaska at a cost of $\$ 14$ per copy. Publication is required by Alaska Stante 41, "to determine the potential of Alaskan land for production of metals, minerals, fuels, and geothermal resources; the location and supplies of groundwater and construction materials; the potential geologic hazards to buildings, roads, bridges, and other installations and structures; and shall conduct such other surveys and investigations as will advance knowledge of the geology of Alaska." 


\section{CONTENTS}

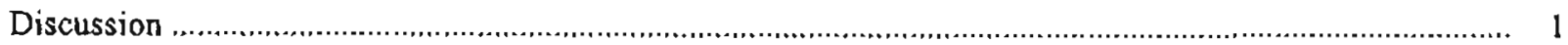

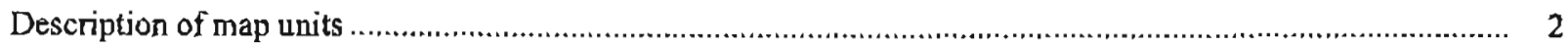

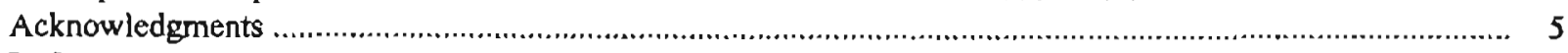

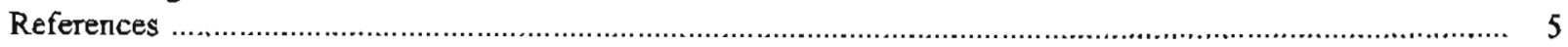

\section{TABLES}

Table 1. .Engineering properties of unconsolidated units ..................................................................

Table 2. . Engineering properties of bedrock units ................................................................................... 5

\section{SHEET}

[in envelope]

Engineering-geologic map of the Chulitna region, southcentral Alaska 


\title{
ENGINEERING-GEOLOGIC MAP OF THE CHULITNA MINING DISTRICT, SOUTHCENTRAL ALASKA
}

\author{
by \\ D.S. Pinney ${ }^{1}$
}

\section{DISCUSSION}

This map illustrates potential near-surface sources of various geologic materials that may be useful for construction. It was derived electronically from bedrock and surficial geologic mapping of the Chulitna region (Clautice and others, 2001), using ARCINFO, a geographic information system (GIS). Field observations indicate that each geologic unit (for example, floodplain alluvium) has a definite composition or range of compositions wherever that unit is found. Therefore, the presence of materials is interpreted from the distribution of geologic units on the geologic map of this quadrangle. This map is generalized and is not intended to show exact locations of specific materiais. The purpose is to indicate general areas where certain geologic materials may be present and to eliminate other general areas from consideration. Local variations are common, especially near unit boundaries.

Potential uses of map units are summarized in the tables below, which show potential availability of various construction materials in each geologic-materials unit. Economic evaluations of specific deposits as sources of construction materials will require detailed examination of each deposit, including areal extent, volume, grain-size variation, thickness of overburden, thermal state of the ground, and depth to water table as well as logistical factors, demand, and land ownership.

This map also identifies the principal geologic hazards that may be associated with various geologic-materials units. Many potential geologic hazards relate directly to map units because (1) the processes that formed the deposits are active and hazardous, and (2) conditions (like ground ice or massive bedrock failures) in the units present hazards if development occurs. The hazards presented on this map are intended only as a general guide to some hazards that might be present at given localities and do not preclude the presence of other unevaluated or site-specific hazards.

Numerous photolineaments suggest that faulting may be pervasive in the area, but evidence for faulting is less obvious in the lowlands, where there are fewer bedrock exposures. This map illustrates lineaments identified during photointerpretation. Faulting and related earthquakes may produce sudden displacements by shaking and impacts and may cause liquefaction and mass movements in botb highlands and lowlands.
A major concern in the highlands is the significant potential for massive landslides because of sackung failures. Over 35 sackungen (plural of the German term sackung) are identified in bedrock areas, where the morphology of many bowl-shaped headwalls and steep sidewalss of glaciated valleys has been significantly modified by sackungen and related bedrock failures. These large features typically form in glaciated alpine terrains in rocks of variable composition (Beck, 1968; Tabor, 1971; Radbruch-Hall and others, 1976, 1977; Bovis, 1982). Driven by gravity, they slowly displace downslope the pervasively faulted and jointed bedrock by creep along ill-defined, shallow to deep zones of bedrock weakness and become progressively more unstable. Eventually, periods of extended rainfall or an earthquake may trigger massive rock failures, including catastrophic rock avalanches, from sackungen. During the period of slow, progressive creep, structures sited on sackungen may be subjected to destructive displacernents.

More than 20 landslides were identified during photointerpretation and fieldwork. Landslides result from the downward and outward movement of slope-forming materials, wherein shear failure typically occurs along a specific surface or combination of surfaces (Schuster, 1978). Aside from the obvious hazords posed by a lange mass of sliding material, even very small amounts of movement can cause substantial engineering or construction difficulties.

In the lowlands, the main hazard concerns are (1) loss or lack of bearing (shear) strength (for example, in saturated, fine-grained alluvium or swamp deposits) and (2) seasonal or outburst flooding. Loss of bearing strength due to liquefaction during earthquakes is likely on the unbraided, fine-grained reaches of the floodplains and low terraces of the Chulitna River. Thick accumulations of seasonal overflow ice (aufeis) should be anticipated in braided reaches of these surfaces and on floodplains of smaller streams as well as on slopes where bedrock is shallow and springs emerge (Sloar and others, 1976).

Other lowland hazards include (1) permafrost, (2) seasonal frost, and (3) debris flows. There are indications of discontinuous permafrost at shallow depth, and during construction of the Alaska Railroad during 1915-1923 the Chulitna area was the railroad's first large-scale excavation in permafrost (Fuglestad, 1986). Differential

'Alaska Division of Geological \& Geophysical Surveys, 794 Unjversity Ave., Suice 200, Fairbanks, Alaska $99709-3645$ 
subsidence due to thawing of ground ice may be a local problem in peats and associated organic soils. Seasonal frost action may be intense in poorly drained, fine-grained sediments. Rapid sedimentation and destructive impact by debris flows derived from fine-grained sediments (like colluvium and complexly interbedded glacial, glaciofluvial, and glaciolacustrine deposits) may be a problem in the upper reaches of small streams, lowland gullies, and on surfaces onto which debris flows debouch.

\section{DESCRIPTION OF MAP UNITS}

\section{Unconsolidated Materials}

(see table 1)

GM Poorly- to moderately well-sorted clay, silt, sand, gravel, and diamicton of colluvial, fluvial, and glacial onigins. Includes angular, unsorted talus debris and chaotically deformed colluvium derived from landslides. Engineering applications vary widely due 10 large range of grain size and sorting properties. Commonly frozen. Estimated 20 to 80 percent coarse, granular deposits with considerable oversized material. Includes primarily GC and GM of the Unified Soil Classification (Wagner, 1957).

GS Fluvial and glaciofluvial gravel, sand, and silt. Chiefly (estimated $>80$ percent) clean sand and gravel. Grain size, sorting and degree of stratification are variable. Permafrost may be present, especially in older deposits. Older deposits may contain highly weathered clasts and thus may not be suitable as construction materials. Rare oversized materials. Includes primarily GP and GW of the Unified Soil Classification (Wagner, 1957).

OR Peat with interbedded organic silt and onganic sand comprising undifferentiated swamp deposits. Chiefly organic-rich silt and peat in bogs and thaw lake basins. Commonly frozen and ice-rich due to the excellent insulating properties of peat. Generally poorly sorted and water-saturated. Estimated $>50$ percent peat, organic sand, or organic silt. Includes $\mathrm{Pt}$ ML, MH, SM, SW, OC, and OL of the Unified Soil Classification (Wagner, 1957).

\section{Bedrock Materials}

(see table 2)

BC Medium-jointed, fine- to coarse-grained sedimentary carbonate rocks. Includes limesione, dolostone, and marble.

BG Coarse-jointed, coarse-grained igneous lithologies. Chiefly granitic rocks.

BM Medium-jointed, fine- to medium-grained quartose sedimentary rocks. Includes quartzose sandstone and conglomerate, quartzite, chert, and homfels.

BV Medium-jointed, fine-grained igneous rocks. Chiefly volcanic flow rock, dikes, and greenstone.

BO Rocks of mixed lithology and very fine-grained sedimentary lithologies that are generally poorly suited for use as construction materials. Includes shale, siltstone, graywacke and argillite. 
Table 1. Engineering properties of unconsolidated units

frost development.
at the base of steed-ice content may be high
where silt and organic materials are heavy precipitation prevalent

GS Good in recently deposited allu- Absent in younger alluvial depos. vium above stream level, fair to its; locally present in older depose-

poor in older alluvium where per- its nantled by silt and peat. May
mafrost has developed and where be present discontinuously in older

covered by silty colfuvium and

free terrace deposiss without

significant cover of organic silt.

older, inactive surfaces mantled by

appreciable thickness
organic materials.

accumulations of peat and organic

sill promote development of seg.

regated ice. Fee is typically limited

present on obler, inactive suy be

of silt and organic materials.

OR Very poor, often with standing waGenerally Generally frozen except near
streatry culs.

Very high. Thaw unstable following surface disturbance.
Thaw unstable; subject to failure due to saturation. crible to heave; heave may oc- sudden, rapid collapse may occur

ter. of silit-a and chending on proportion stage of permafrost development. Deposits on o ra hebsers avalanches and torrestial flooding

rergandic sht or where silt has infil-

ground water. Sporadic where

present on older, inactive surfaces
Bearing
strength

\section{Potential primary}

$\begin{array}{ll}\text { High in deposits that contain large } & \text { Thaw unstable where perennially } \\ \text { proportions of silt or organic silt } & \text { frozenz or where deposit contains }\end{array}$

and in deposits with poor drainage. excess ice. Deposits of predomi-

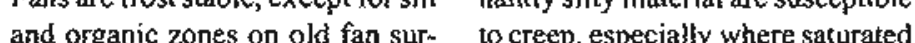

faces, especially where shallow per- by near-surface cround water, such

as springs along faults. Steep collu-

vial deposits, such as talus aprons

at or near the angle of repose, are

geaerally unstable and may be sub-

ject to snow avalanches, debris
flows, and rock falls Fans are gent

erally stable, except where overbur-
den is susceptible to frost heaving.

Minimal in welt-drained modern Generally stable, except for ice-rich Variable, but generally good to Crushed aggregates and miscel-

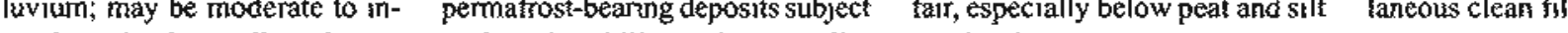

ther sill and peat. To thaw instabiliy and areas adjer

due to stream erosion or surface

loading. Fill terraces may be sub-

ject to siumping and rapid erosion.

fair, especiall b

$\left(\frac{100}{20}\right.$
local pods or terseses may be a source of small quantities of moderately
sorted, gravel-rich fluvial sand

\section{Potential engineering considerations}

Unciassified fills, although some

Fan surfaces may be subject to snow avalanches, debris flows, sub-
sidence, and local liquefaction. sidence, and local liquefaction.
Therefore, caution should be exerTherefore, caution should be exer-
cised durisg excavation and construction activities. Saturated or thaw subsidence may occur in areas of perraaffost.
Generally poor, especially where thawed.
May be suitable for horticultural or energy applications. over-steepened deposits may be
subject to slope failure, and tocal

Older deposits that contain perma- Qa, Qac, Qao, Qao?, Qat, Qfp, frost and have significant cover of eolian, organic, or colluvial sedin. ments are generally undesirable as tributaries may have high potential for debris flows or snow avalanches. Curbanks along active streams may fail, thus may not be suitable for stsucture sitess. High flooding potential along margins of
streams.

Component geologic

Qaf, Qc, Qef, Qcl, Qcl?, Qct,

$h, \Upsilon_{s}$

Surface subject to inundation, exreme frost heaving, and thaw subsidence in salurated soils. Generally unsuitable as structure sites
unless structures are pile supported.

\section{Qs} Qd, Qd1?, Qrg, Q11, Qt?? 
Table 2. Engineering properties of bedrock units

\begin{tabular}{|c|c|c|c|}
\hline Map unit & Principal rock characteristics & Potential primary products & Component geologic units \\
\hline $\mathrm{BC}$ & $\begin{array}{l}\text { Medium-jointed, fine- to coarse- } \\
\text { grained sedimentary carbonate rocks }\end{array}$ & $\begin{array}{l}\text { - Dimension stone } \\
\text {-Ornamental stone } \\
\text {-Crushed rock } \\
\text {-Cement }\end{array}$ & DI, ITRI, PI, UTRI \\
\hline BG & $\begin{array}{l}\text { Coarse-jointed, coarse-grained } \\
\text { igneous rocks }\end{array}$ & $\begin{array}{l}\text {-Dimension and omamental stone } \\
\text {-Riprap, armor, gabion and drain rock } \\
\text {-Crushed rock and grüs }\end{array}$ & $\mathrm{Kg}, \mathrm{Km}, \mathrm{Tg}$ \\
\hline $\mathrm{BM}$ & $\begin{array}{l}\text { Medium-jointed, fine- to } \\
\text { medium-grained quartzose } \\
\text { sedimentary rocks }\end{array}$ & $\begin{array}{l}\text {-Riprap and drain rock } \\
\text {-Crushed rock } \\
\text {-Unclassified fills }\end{array}$ & $\begin{array}{l}\text { Dc, KJc, KJs, KJsa, } \\
\text { TRrb, TRs }\end{array}$ \\
\hline $\mathrm{BV}$ & $\begin{array}{l}\text { Medjum-jointed, fine-grained } \\
\text { igneous rocks }\end{array}$ & $\begin{array}{l}\text {-Riprap and drain rock } \\
\text {-Crushed rock } \\
\text {-Unclassified fills }\end{array}$ & $\mathrm{Dv}, \mathrm{Tb}, \mathrm{TR} b, \mathrm{TRJb}, \mathrm{uPzt}$ \\
\hline $\mathrm{BO}$ & Other lithologies & $\begin{array}{l}\text {-Unclassified fills } \\
\text {-Serpentinite may be suitable } \\
\text {-as an ornamental stone }\end{array}$ & $\begin{array}{l}\text { Jac, Js, KJas, PPs, sp, } \\
\text { sp", TRvs, UPzs, uPzst }\end{array}$ \\
\hline
\end{tabular}

\section{ACKNOWLEDGMENTS}

Rodney A. Combellick (ADGGS) and Richard D. Reger (ADGGS, retired) reviewed this map and offered many constructive comments that improved it. I greatly appreciate their input.

\section{REPERENCES CITED}

Beck, A.C., 1968, Gravity faulting as a mechanism of topographic adjustment: New Zealand Journal of Geology and Geophysics, v. 11, no. 1, p. 191-199.

Bovis, M.J., 1982, Uphill-facing (antislope) scarps in the Coast Mountains, southwest British Columbia: Geological Society of America Bulletin, v. 93, no. 8, p. 804-812.

Clautice, K.H, Newberty, R.J., Pinney, D.S., Blodgett, R.B., Bundtzen, T.K., Gage, B.G, Hartis, E.E., Liss, S.A., Miller, M.L., Reifenstuhl, R.R., and Clough, J.C., 2001, Geologic map of the Chulitna region, soutbcentral Alaska: Alaska Division of Geological \& Geophysical Surveys Report of Investigations 2001-lb, I sheet, scale 1:63,360, $32 \mathrm{p}$.

Fuglestad, T.C., 1986, The Alaska Railroad between Anchorage and Fairbanks: Guidebook to permafrost and engineering problems: Alaska Division of Geological \& Geophysical Surveys Guidebook 6,82 p.
Radbruch-Hall, D.H., Varnes, D.J., and Savage, W.Z., 1976, Gravitational spreading of steep-sided ridges ("sackung") in western United States: Engineering Geology, no. 14, p. 23-35.

Radbruch-Hall, D.H., Varnes, D.J., and Colton, R.B., 1977, Gravitational spreading of steep-sided ridges ("sackung") in Colorado: U.S. Geological Survey Joumal of Research, v. 5, no. 3, p. 359-363.

Schuster, R.L., 1978, Chapter 1: Introduction: in Schuster, R.L., and Krizek, R.J., (eds.) Landslides: Analysis and control, Transportation Research Board, National Research Council Special Report 176.

Sloan, C.E., Zenone, Chester, and Mayo, L.R., 1976, Icings along the trans-Alaska pipeline route: U.S. Geological Survey Professional Paper 979, 31 p.

Tabor, RW., 1971, Origin of ridge-top depressions by large-scale creep in the Olympic Mountains, Washington: Geological Society of America Bulletin, v. 82, no. 7. p. 1811-1822.

Wagner, A.A., 1957, The use of the Unified Soil Classification System by the Bureau of Reclamation: Proceedings, 4th lnternational Conference on Soil Mechanics and Foundation Engineering (London), vol. I, p. 125. 